\title{
Dlx5 and Dlx6 can antagonize cell division at the $\mathrm{G}_{1} / \mathrm{S}$ checkpoint
}

\author{
Rachel K. MacKenzie, Parvathy Ravi Sankar and Andrew J. Bendall ${ }^{*}$ (i)
}

\begin{abstract}
Background: D/x5 and D/x6 stimulate differentiation of diverse progenitors during embryonic development. Their actions as pro-differentiation transcription factors includes the up-regulation of differentiation markers but the extent to which differentiation may also be stimulated by regulation of the cell cycle has not been addressed.

Results: We document that expression of D/x5 and D/x6 antagonizes cell proliferation in a variety of cell types without inducing apoptosis or promoting cell cycle exit. Rather, a variety of evidence indicates that elevated D/x5 and D/x6 expression reduces the proportion of cells in $S$ phase and affects the length of the cell cycle.

Conclusions: Antagonism of S-phase entry by Dlx 5 and Dlx6 proteins likely represents a lineage-independent function to effect Dlx-mediated differentiation in multiple progenitor cell types.
\end{abstract}

Keywords: Dlx genes, Cell cycle, Checkpoint, Proliferation

\section{Background}

Embryonic development unfolds as a series of cell autonomous and extracellular transactions that define each cell's capacity to divide or differentiate. The rapid cycling of early blastomeres in metazoan embryos gives way to longer and more heavily regulated cell cycles [1] that can respond to differentiation-inducing conditions and generate committed, lineage-restricted, progenitors. Subsequently, terminal differentiation is typically accompanied by a permanent cell cycle exit $[2,3]$. The reciprocal relationship between cellular proliferation and differentiation points to a tight coordination between cell cycle dynamics and cell fate, with the time spent in G1 being particularly important. A short G1 phase corresponds to pluripotency in embryonic stem cells $[4,5]$ and neural precursors undergoing proliferative cell divisions have a shorter G1 phase which lengthens when neurogenic divisions commence $[6,7]$. The importance of the time spent in $\mathrm{G} 1$ for differentiation has been demonstrated by experimental manipulation of CDK activity; an artificially lengthened G1 phase is sufficient to induce neuronal differentiation [8]. Indeed, a number of cell type-specific transcription factors are known to promote cellular differentiation, at least in part, by directly controlling the

\footnotetext{
* Correspondence: abendall@uoguelph.ca

Department of Molecular and Cellular Biology, University of Guelph, 50 Stone Rd East, Guelph, Ontario N1G 2W1, Canada
}

expression or function of cell cycle regulators. Classic studies involving the muscle-specific regulatory transcription factor MyoD revealed that its function as a master regulator of myogenesis involved the activation of CDK inhibitors $[9,10]$, genes that are likely direct physiological targets of the transcription factor [11]. Up-regulation of cell cycle antagonists by differentiation-inducing transcription factors is likely a broadly applicable mode of action, since $p 21^{\text {WAF1/CIP1 }}$ has also been identified as a target of erythroid-specific factors GATA-1 [12] and EKLF [13]. Alternatively, the down-regulation of cyclin-encoding genes can lead to the same functional outcome; NEUROG2 acts to repress the transcription of various cyclins via direct and indirect means [14]. Prospero does both in Drosophila neuroblasts, inhibiting cyclin $E$ and the $c d c 25$ homologue string while activating the CDK inhibitor dacapo $[15,16]$. It should be noted that expression of such differentiation-inducing factors is not incompatible with cell division; rather, mechanisms exist to maintain the proliferative capacity of lineage-committed progenitors. In myogenic precursors, MyoD function is inhibited by the actions of cyclin D1 $[17,18]$ and NEUROG2 target gene selection is modified by CDK-dependent phosphorylation $[19,20]$.

Vertebrate $D l x$ genes constitute a family of cell-type specific transcription factors that promote the differentiation of a variety of very different cell types including

(c) The Author(s). 2019 Open Access This article is distributed under the terms of the Creative Commons Attribution 4.0 International License (http://creativecommons.org/licenses/by/4.0/), which permits unrestricted use, distribution, and 
cortical and olfactory interneurons, chondrocytes, osteoblasts, and ameloblasts, as well as cells in the basal epidermis, and placenta [21-27]. In particular, the co-expressed paralogs $D l x 5$ and $D l x 6$ are required for the proper maturation and function of cortical [28] and olfactory bulb interneurons [29-32], and sensory cells of the inner ear [33-36], as well as the differentiation of chondrocytes and osteoblasts [35-38]. There is a significant body of evidence to indicate that the pro-differentiation functions of Dlx5 and Dlx6 proteins include their actions as transcriptional activators of lineage-specific genes that define the differentiated cell type [39-43] or of other regulators of lineage-specific differentiation $[40,44-51]$. Thus, the differentiation function of Dlx 5 is understood on the basis of the activation of lineage-specific markers. In contrast, the effects of Dlx factors on the cell cycle has not been systematically studied. To do so has become increasingly important given numerous observations that elevated $D l x$ gene expression in a variety of solid tumors and hematologic malignancies is compatible with deregulated proliferation [52-56]. To address this deficiency in our understanding of $D l x$ gene function during development we have characterized the effect(s) of Dlx5 and Dlx6 on cell division in a variety of non-tumorigenic cell types. Consistently, we find that expression of these homeodomain regulators antagonizes proliferation without stimulating apoptosis or promoting cell cycle exit. Rather, several lines of evidence points to the $G_{1} / S$ transition as a key locus of control.

\section{Results}

\section{Forced expression of Dlx5 and Dlx6 is sufficient to antagonize cell growth}

There has been no systematic investigation of the degree to which the up-regulation of $D l x$ gene expression in differentiating tissues impacts the cell cycle or whether there is a specific step in cell cycle progression that is regulated by Dlx proteins. To test the sufficiency of Dlx 5 and Dlx6 to antagonize cell division and the generality of this effect we initially tested cell populations that are not known to differentiate in response to endogenous $D l x$ gene expression. We transfected the immortalized chick fibroblast cell line DF-1 with avian retroviral plasmids encoding chicken Dlx5 or Dlx6 and relied on secondary transduction by replication-competent virus in culture to achieve widespread $D l x$ misexpression. Expression of Dlx 5 or Dlx6 in DF-1 cells resulted in a much reduced rate of cell accumulation in vitro (Fig. 1a). We also tested whether DNA binding by Dlx5 was required for this effect by expressing a Dlx 5 protein $\left(\mathrm{Dl} 55 \mathrm{HD}^{\mathrm{m}}\right)$ with amino acid substitutions in the amino-terminal arm of the homeodomain [57]. DF-1 cells expressing Dlx5 $\mathrm{HD}^{\mathrm{m}}$ grew indistinguishably from DF-1 cells transduced with the empty retrovirus. Thus, the effects of Dlx 5 on cell growth in vitro appears to require the DNA binding activity of the homeodomain and, given the very high level of conservation between Dlx homeodomains [22], the same would hold true for Dlx6. We next mis-expressed murine Dlx5 or Dlx6 in the human embryonic kidney epithelial cell line HEK293. The mouse and human Dlx5 and Dlx6 proteins are 97 and $96 \%$ identical respectively, permitting the use of this heterologous cell line. Transfected HEK293 cells were selected to enrich for Dlx-expressing cells then cultured without further selection. Again, both Dlx5 and Dlx6 suppressed the rate of cell accumulation over 4 days (Fig. 1b).

We next tested two cell populations that are known to activate expression of $D l x 5$ and differentiate in response to developmental signaling cues. The myogenic mesenchymal cell line $\mathrm{C} 2 \mathrm{C} 12$ will trans-differentiate into osteoblasts in response to BMP signaling, an effect that is mediated by $D l x 5$ [58-61]. Indeed $D l x 5$ is sufficient to activate downstream osteogenic regulators in this cell line in the absence of BMP ligand [59]. Transfected $\mathrm{C} 2 \mathrm{C} 12$ cells were selected to enrich for $D l x$-expressing cells then cultured without further selection. As we observed for DF-1 and HEK293 cells, both murine Dlx5 and Dlx6 suppressed the rate of cell accumulation over 4 days (Fig. 1c). Finally, we tested the effects of these genes in primary cells from the early limbs of the chick embryo since $D l x 5$ expression is induced in response to chondrogenic signals in the mesenchymal core of the early limb bud [57]. Transiently transfected primary limb bud cells were grown as above and were similarly affected by forced expression of chick $D l x 5$ and $D l x 6$ (Fig. 1d). For all cell types, the strongest effects were seen in the first $48 \mathrm{~h}$ after seeding such that both the rate of cell accumulation and the total cell number at the end of the assay were significantly lower. Since C2C12 cells represent a well studied multipotent progenitor cell model that is responsive to Dlx5-mediated differentiation we focused further analysis on this cell line. For all experiments $\mathrm{C} 2 \mathrm{C} 12$ cells were grown under growth-promoting, rather than differentiation-inducing, conditions.

\section{Dlx-mediated antagonism of cell growth is not the result of increased cell death or cell cycle exit}

To assess the extent to which increased levels of cell death may have contributed to the reduced accumulation of Dlx5- or Dlx6-expressing cells we measured levels of activated Caspase- 3 in the same transfected and selected cells that were used for the growth assay. Levels of activated Caspase- 3 in both Dlx 5 and Dlx6-expressing cells were indistinguishable from the vector control cells at day zero of the growth assay (Fig. 2a). Thus apoptotic pathways were not activated over control levels during 

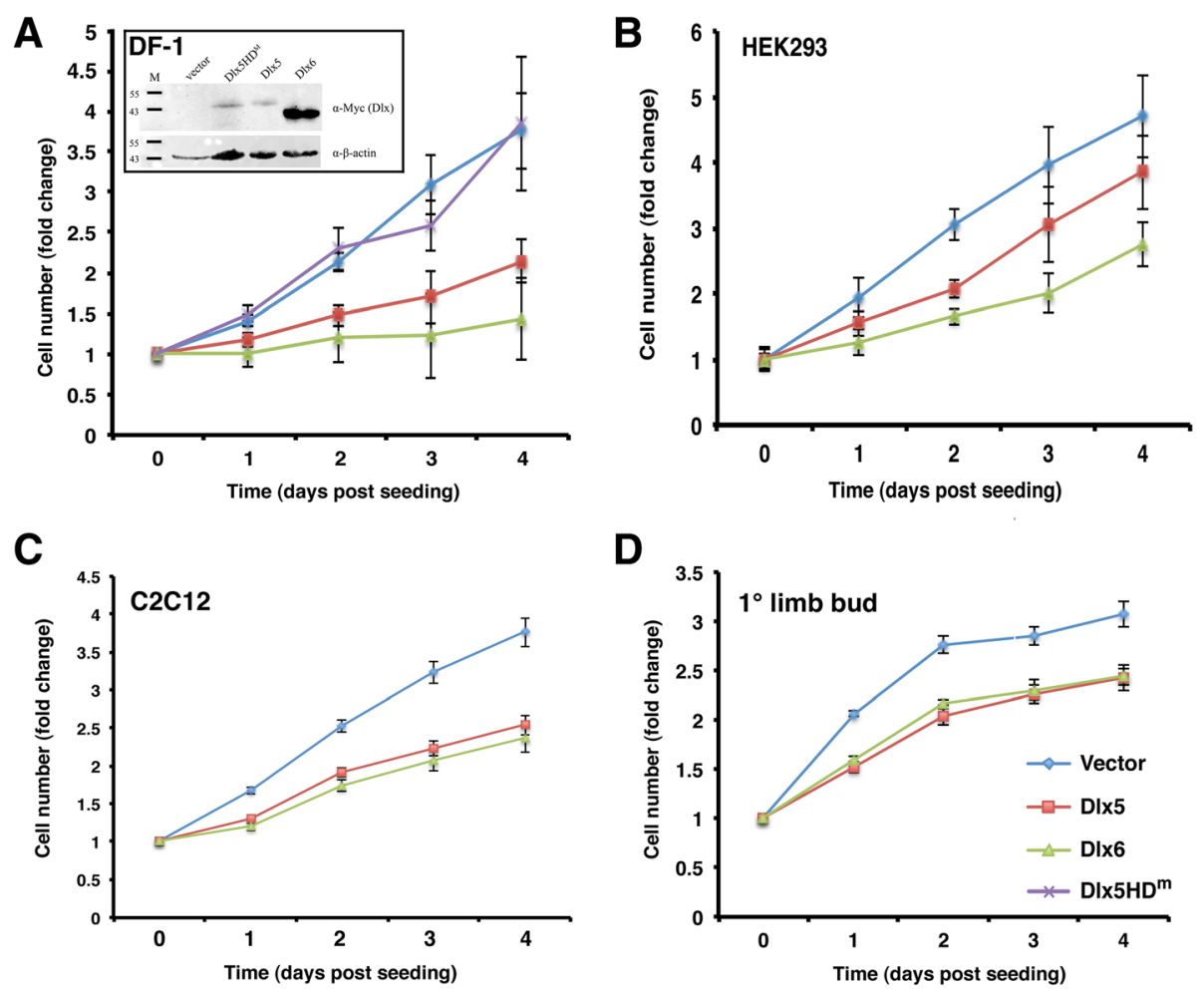

Fig. 1 Dlx proteins inhibit growth of a variety of cell types. a Transfected and transduced DF-1 cells were seeded in triplicate at $1.2 \times 10^{4}$ cells/ well in a 96-well plate. Stable expression of myc-tagged proteins was confirmed by immunoblotting (inset). b Transfected and selected HEK293 cells were seeded in triplicate at $1 \times 10^{4}$ cells/well in a 96-well plate without further selection. c Transfected and selected C2C12 cells were seeded in triplicate at $1 \times 10^{4}$ cells/well in a 96-well plate without further selection. $\mathbf{d}$ Chick embryo limb bud cells plus transfected DNA mixture was seeded directly into 96-well plates, in triplicate, at $4 \times 10^{4}$ cells/well. In all panels, relative changes in cell number were measured daily for 4 days using resazurin. All assays were done a minimum of three times for each cell type. Linear regression analysis was performed on the initial increase in cell numbers, and the slopes of the regression lines were compared using the "Comparison of Regression Lines" function in Prism. The slopes of all Dlx5 and Dlx6 regression lines were determined to be significantly different from their respective vector controls

the post-transfection period of G418 selection. To rule out that either Dlx protein induced apoptosis over the course of the growth experiment we seeded similarly-selected cells and measured levels of activated Caspase-3 over 3 days. We recovered detached cells along with the adherent monolayer to ensure a complete recovery of dead and dying cells. Active Caspase- 3 activity declined over the course of 3 days and at no time did Dlx-expressing cells have elevated levels of Caspase-3 compared to the empty vector control cells (Fig. 2b). We independently confirmed this observation by TUNEL labeling in $\mathrm{C} 2 \mathrm{C} 12$ cells transiently transfected with Dlx5- or Dlx6-expression plasmids (Fig. 2c, d). In this experiment we could compare Dlx-positive cells to the untransfected cells in the same dish. The proportion of TUNEL-positive cells actually averaged lower in Dlx5or Dlx6-expressing $\mathrm{C} 2 \mathrm{C} 12$ cells (about 3\%) compared to co-cultured Dlx-negative cells (5-6\%), although the difference did not reach statistical significance (Fig. 2d). Collectively this data supports the interpretation that the reduced cell accumulation we observed in several cell types results from a negative influence on cell division by Dlx 5 and Dlx6.

We next asked whether Dlx5 and Dlx6-expressing cells remained in the cell cycle or whether expression of these proteins promoted withdrawal into $\mathrm{G}_{0}$. We therefore quantitated the proportion of Ki67-positive cells in Dlx-expressing and control cells. Transiently transfected C2C12 cells were monitored daily between 2 and 4 days post-transfection by co-detection of exogenous transfected protein and endogenous Ki67. The proportion of Ki67-positive cells was quantitated for both transfected and non-transfected cells in the same culture and compared to empty-vector transfected cultures (Fig. 3). As expected, the proportion of Ki67-expressing cells decreased over time as the cultures became confluent and cells entered quiescence. At each time point examined though, the proportion of actively cycling Dlx5-positive cells was indistinguishable from untransfected cells in the same dish and were not statistically different from the empty-vector transfected populations (Fig. 3a). Equivalent results were obtained when the 

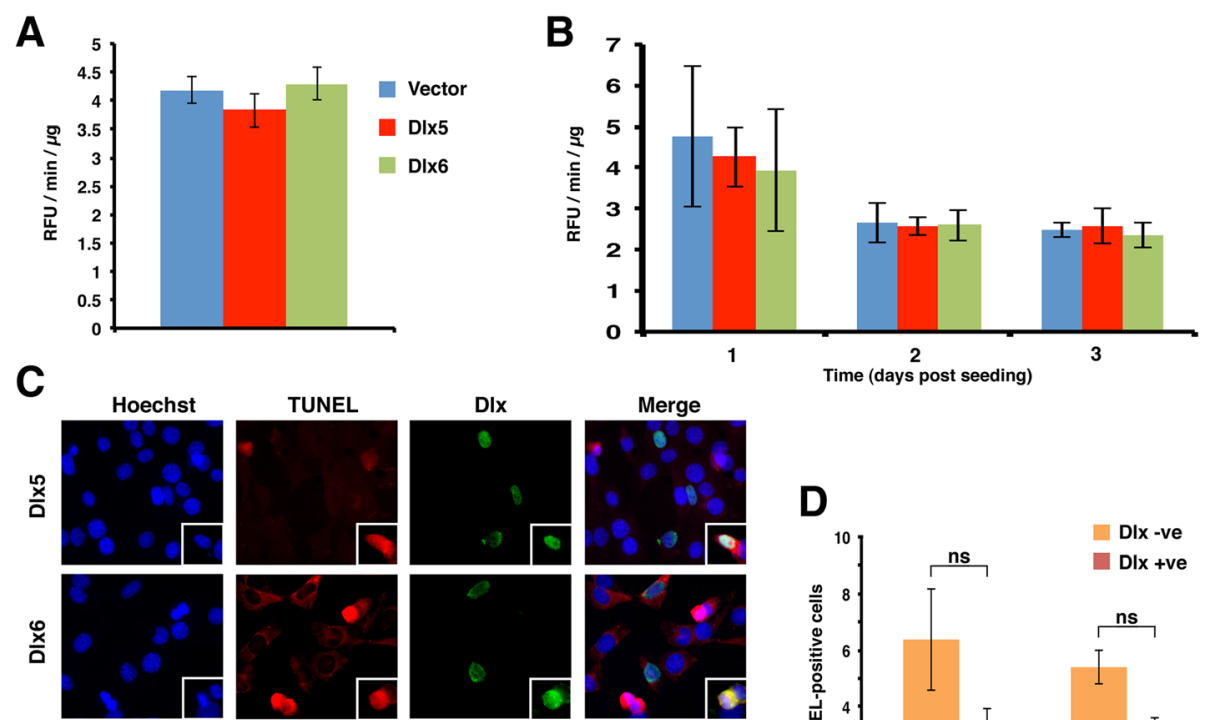

TUNEL
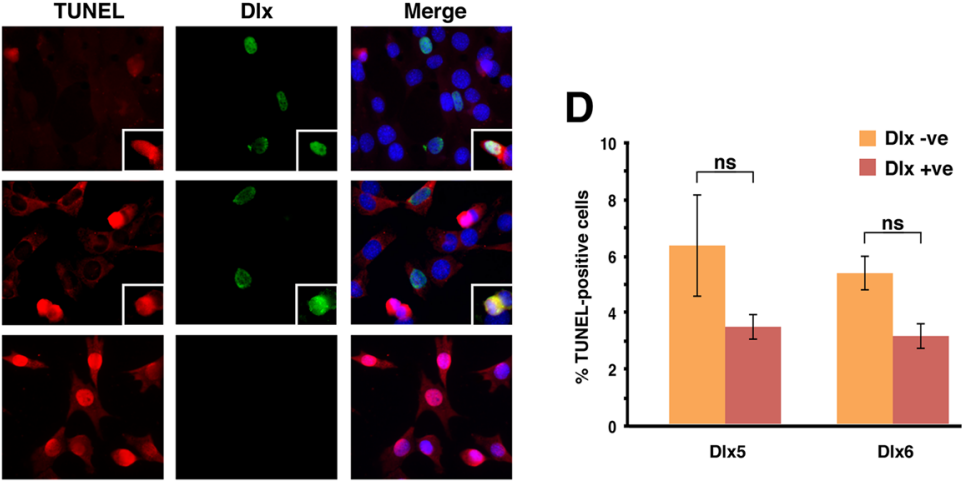

Fig. 2 D/x-expressing C2C12 cells do not show elevated levels of apoptosis. a At the time of seeding the resazurin viability assay, extra C2C12 cells were collected to assess caspase-3 activation levels. Bars represent the average caspase-3 activity, reported as Relative Fluorescence Units per minute per microgram (RFU/min./Mg), + /- the standard error of the mean (SEM). b C2C12 cells were transfected and selected in the same manner as for the proliferation assay $(n=2)$. After 4 days of selection, cells were seeded into 6 -well plates in triplicate, at a density of $1.9 \times 10^{5}$ cells/well. At 24, 48 and 72 h-post seeding, floating and adherent cells were collected and extracts assayed for caspase-3 activity. Bars represent the average caspase-3 activity (RFU/min./Mg) +/- SEM. There was no significant difference in caspase-3 activation in any D/x5- or D/x6-transfected populations compared to the vector control at any time point (ANOVA). c, d Proliferating C2C12 cells were transiently transfected during seeding onto poly-D-Lysine-coated coverslips and double strand DNA breaks were detected $24 \mathrm{~h}$ post-transfection. (c) Representative pictures taken with a 40x objective lens. Insets are examples of Dlx-positive and TUNEL-positive cells. $\mathbf{d}$ The proportion of D/x-expressing cells undergoing apoptosis was compared to the surrounding Dlx-negative population. Bars represent two experiments \pm SEM, with at least 100 Dlx-positive cells counted in each. No significant differences in \% TUNEL labeling were detected (ANOVA)
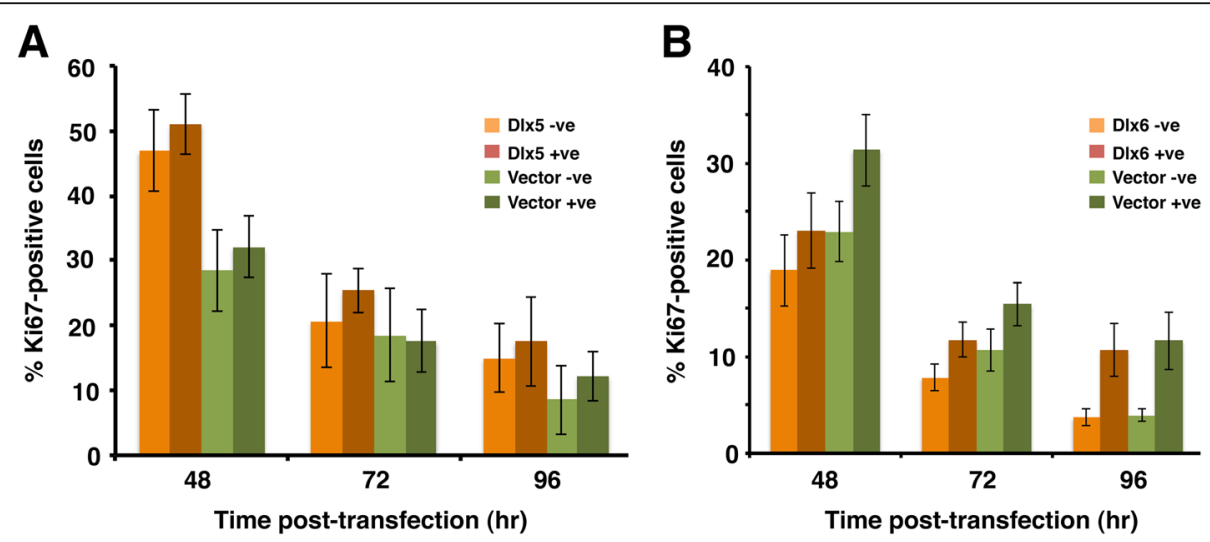

Fig. 3 Dlx proteins do not promote cell cycle exit. a Proliferating C2C12 cells were co-transfected with a nuclear GFP-encoding plasmid and either a Dlx5-encoding plasmid or an empty vector and seeded onto poly-D-Lysine-coated coverslips. Ki67 and GFP were detected at the times shown post-transfection. The proportion of actively cycling (Ki67-positive) cells was determined for both the transfected and non-transfected populations on each slide. Bars represent the averages from a minimum of three experiments \pm SEM, with at least 300 GFP-positive cells counted in total. b As for A, with Dlx6-encoding plasmid. No significant difference was detected at any given time point for any two-way comparison (unpaired $t$-tests) 
Ki67 status of Dlx6-transfected C2C12 cells was quantitated (Fig. 3b). Thus, neither Dlx5 nor Dlx6 induces quiescence in $\mathrm{C} 2 \mathrm{C} 12$ cells cultured under growth-promoting conditions.

\section{Dlx5 and Dlx6 antagonize entry into S-phase}

We next wanted to know whether there was a specific point of the cell cycle that was susceptible to Dlx 5 or Dlx6 misexpression. In the course of testing the growth effects of Dlx 5 and Dlx6 on a variety of cell lines we noted that HEK293T cells were refractory to the growth-inhibitory effects of these proteins (Fig. 4). HEK293T cells differ from the parental HEK293 line in that they express the large T antigen of SV40 [62] and it is known that this viral protein promotes passage through the $G_{1} / S$ checkpoint via antagonism and functional subversion of Rb and p53 [63-67]. We therefore focused on this checkpoint and characterized the DNA replication status of Dlx-expressing $\mathrm{C} 2 \mathrm{C} 12$ cells. Transfected cells were incubated in the presence of 5-ethynyl-2'-deoxyuridine (EdU), a thymine analogue. Incorporation of EdU into newly synthesized DNA indicates that the cell was in S phase at some point during the labeling period. Comparison of the proportion of EdU-positive cells in the Dlx5 and Dlx6-positive populations to the Dlx-negative cells on the same slide, as well as to the empty vector-transfected population, revealed that significantly fewer Dlx-expressing cells were in S-phase at the time of EdU labeling. Specifically, the labeling index (LI) of $D l x$-expressing cells was close to $20 \%$ compared to $60 \%$ for all Dlx-negative populations (Fig. 5a, b).

A reduction in EdU incorporation in Dlx-expressing cells could be due to a reduction in the proportion of actively dividing cells or a lengthening of the cell cycle. In order to distinguish between these possibilities, we used a cumulative labeling method to estimate cell cycle length and the growth fraction (GF), defined as the number of cells in a population that are actively undergoing cell division [68]. EdU was added to the media of transfected cells and incubated for $30 \mathrm{~min}$ to $36 \mathrm{~h}$. Cells were collected at each time point, and the LI of Dlx-positive and Dlx-negative cells was determined. The LI of both Dlx-positive and Dlx-negative cell populations increased linearly until the entire growth fraction had been labeled. While $D l \times 5$ and Dlx6-expressing cells reached a GF of 76 and $75 \%$ respectively, the Dlx-negative populations surrounding each of them exhibited a GF of $94 \%$ (Fig. 5c, d). While the slopes of the linear increase were not determined to be significantly different in the Dlx-positive populations compared to the Dlx-negative populations, the length of time required to reach maximum labeling was increased by approximately $6 \mathrm{~h}$ in both the Dlx 5 and Dlx6-expressing cells (Table 1).

Finally, we used flow cytometry analysis to ask whether Dlx proteins were affecting the cell cycle at other checkpoints. Proliferating $\mathrm{C} 2 \mathrm{C} 12$ cells were transfected and selected in the same manner as for the alizarin growth assay. After 4 days of selection, each cell population was seeded at equal density into 3 separate plates. $24 \mathrm{~h}$ post transfection, one plate was collected for analysis and the other two plates were re-seeded to the starting cell density to ensure that cell crowding did not influence the cell cycle profile. We focused on $48 \mathrm{~h}$ post selection when the maximal effect was seen, namely a reduction in the proportion of cells in S phase concomitant with an increase in the proportion of cells in the G1/G0 fraction (Fig. 5e, f). There was no significant change in the size of the G2/M fraction at any time point, arguing that Dlx proteins were not separately limiting entry into G2, or completion of mitosis. Flow cytometry analysis was also done on unselected, transiently transfected, $\mathrm{C} 2 \mathrm{C} 12$ populations $24 \mathrm{~h}$ post transfection. At $15 \%$ transfection efficiency, no effect was seen,

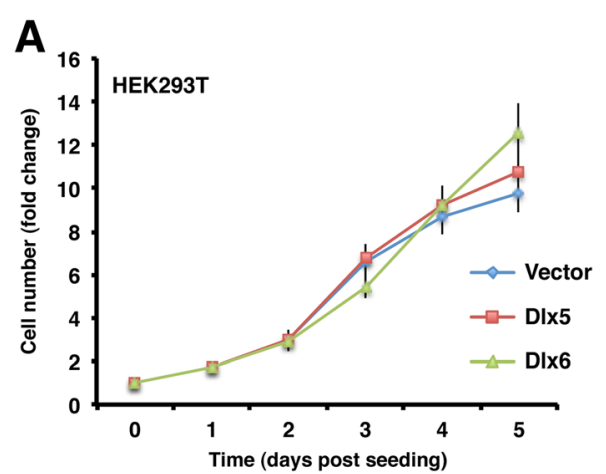

B

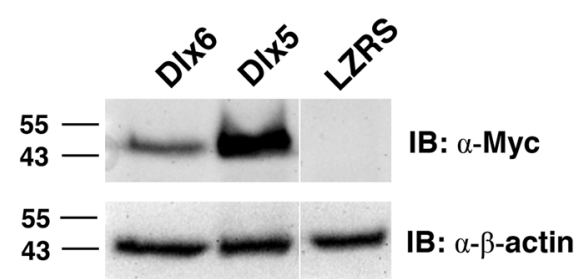

Fig. 4 HEK293T cells are refractory to the growth suppressing effects of forced D/x expression. a Transfected and selected HEK293T cells were seeded in triplicate at $1 \times 10^{4}$ cells/well in a 96-well plate without further selection. Relative changes in cell number were measured daily for four days with resazurin $(n=4)$. b At the time of seeding the growth assay, extra cells were collected for immunoblot (IB) analysis to verify protein expression. Molecular mass standards are shown at left 

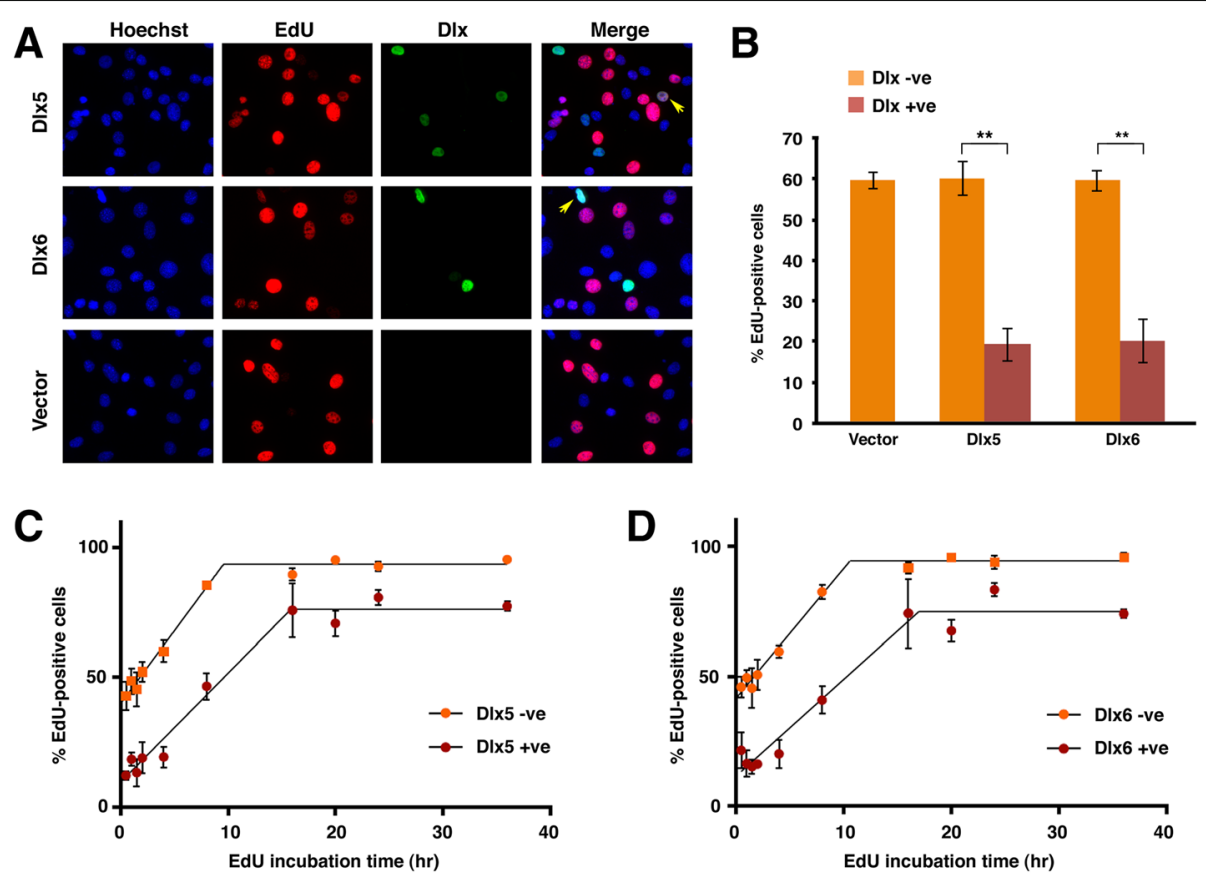

E

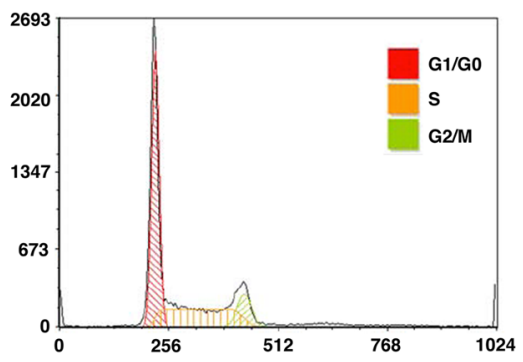

$\mathbf{F}$

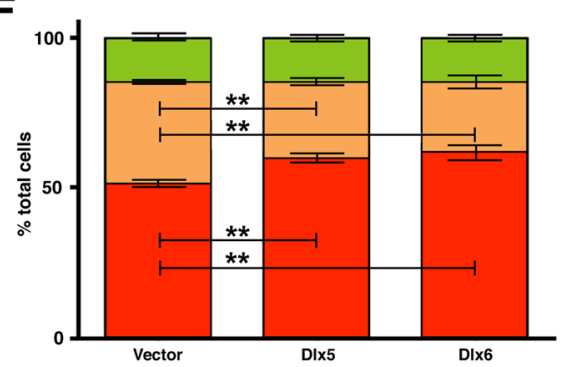

Fig. 5 Dlx proteins limit entry into S-phase. a, b Proliferating C2C12 cells were transfected and seeded onto poly-D-Lysine-coated coverslips and DNA synthesis was detected 24-h post transfection by incorporation of EdU for $4 \mathrm{~h}$. a Representative pictures taken with a 40x objective. Yellow arrows point to Dlx-positive cells that have incorporated EdU during the incubation time. $\mathbf{b}$ Quantitation of the labeling index (LI), defined as the ratio of EdU-positive nuclei to total cells. Bars represent the average LI, +/- SEM from 3 experiments, with at least 200 Dlx-positive cells counted per experiment. ${ }^{* *} p<0.01$ (unpaired $t$-test). $\mathbf{c}, \mathbf{d}$ C2C12 cells, treated as above, were labeled with EdU for various times to measure the growth fraction (GF) and cell cycle length. Each time point represents a minimum of three experiments. LI is plotted over time for (c) Dlx5- and (d) Dlx6expressing cells. Slopes of the initial linear increases, as determined by linear regression analysis, were compared in Prism using the "Comparison of Regression Lines" function. Neither Dlx5 nor Dlx6 significantly altered the rate of EdU incorporation, compared to the surrounding Dlx-negative cells (Dlx $5 p=0.07 ; \mathrm{D} 1 \times 6 p=0.14$ ). GF was set as the mean of all points following the initial linear increase. The elevations of the GF reached by Dlx-positive and Dlx-negative cells were compared using the "Comparison of Regression Lines" function in Prism, and both proteins were found to significantly alter the GF, compared to the surrounding Dlx-negative cells (Dlx5, Dlx6 $p<0.0001$ ). e, $\mathbf{f}$ Transfected C2C12 cells were selected over a period of 4 days then $8 \times 10^{5}$ cells were seeded into $6 \mathrm{~cm}$ plates. Cells were collected for flow cytometric analysis and extra cells were replated at the original density every $24 \mathrm{~h}$. e Representative flow cytometry histogram at $48 \mathrm{~h}$ post selection. Scaling on both axes is linear. $\mathbf{f}$ Quantitation of flow cytometry data. Bars represent the mean of all experiments $(n=4)+/-$ SEM; G1/G0 (red), S (orange), G2/M (green). Both Dlx5- and Dlx6-expressing populations contained a reduced proportion of cells in S-phase, with a compensatory increase in $G_{1} .{ }^{* *} p<0.0001$, unpaired $t$-test

but at $30 \%$ transfection efficiency there was a $6 \%$ increase in the proportion of G1/G0 cells in Dlx-transfected populations in comparison to the vector-control population (data not shown). Collectively these data provide an explanation for the growth-inhibitory effects of Dlx5 and Dlx6, namely antagonism of entry into $S$ phase.

\section{Discussion}

The action of $D l x$ genes to promote differentiation in divergent cell lineages and the intimate connections between cellular proliferation and differentiation suggests that interactions with core cell cycle regulators could give a fuller picture of Dlx protein functions during development. In this study we demonstrated that forced 
Table 1 Estimation of cell cycle length in C2C12 cells

\begin{tabular}{lllll}
\hline Population & $\begin{array}{l}\text { Growth fraction } \\
(\%)\end{array}$ & Slope of linear increase & $\begin{array}{l}\text { Cell cycle length } \\
\text { (GF/slope; hr) }\end{array}$ & $\begin{array}{l}\text { Time to LI max } \\
\text { (hr) }\end{array}$ \\
\hline Dlx5+ve & 76 & 4.2 & 18 & 16 \\
Dlx5 -ve & 94 & 5.6 & 17 & 10 \\
Dlx6+ve & 75 & 3.7 & 20 & 17 \\
Dlx6 -ve & 94 & 5.0 & 19 & 11 \\
\hline
\end{tabular}

* time to maximum labeling index

expression of $D l x 5$ or $D l x 6$ is sufficient to antagonize growth in a variety of cell types. In a cell type that undergoes Dlx-mediated differentiation, the effects on cellular proliferation were explained by antagonism of entry into S-phase. The reduced accumulation of Dlx5or Dlx6-expressing cells could not be explained by elevated levels of apoptosis in the bulk population (Fig. 2). We could also not detect an increased proportion of Dlx-expressing cells in $\mathrm{G}_{0}$ by the criteria of Ki67 levels (Fig. 3), leading us to examine cell cycle kinetics. While the reduced growth fraction in Dlx-expressing cells (Fig. 5c, d) might otherwise be taken as evidence of a subpopulation of cells in $G_{0}$, the continued expression of Ki67 in Dlx-expressing cells suggests instead that a fraction of the Dlx-expressing cells are not completing their cell cycle over a $36 \mathrm{~h}$ period. This latter effect may be an artifact of very high protein levels in affected cells where the block to S-phase becomes "permanent".

We note that their known effects on differentiation make loss-of-function experiments involving $D l x$ genes difficult to interpret when it comes to their roles in regulating proliferation. Preventing $D l x$ expression all together, as has been done in multiple knockout mouse models, delays differentiation in Dlx-dependent cell types but doesn't result in an obvious overgrowth phenotype [34, 38, 69-72]. Conversely, knocking down $D l x$ expression later in development is not expected to revert cells to a proliferating progenitor state. Exploration of the mechanisms of action of Dlx proteins at the $\mathrm{G}_{1} / \mathrm{S}$ checkpoint will therefore largely depend on gain-of-function experiments until more mechanistic details emerge and more targeted loss-of-function assays can be done.

It some embryonic cellular contexts, expression of $D l x 5$ and $D l x 6$ is both compatible with proliferation and required for continued tissue expansion. For example, limb bud mesenchyme continues to divide normally in the absence of both $D l \times 5$ and $D l \times 6$ function but proliferation in the adjacent AER does not [38]. A similar situation exists in the otic vesicle [34, 38]. Notably, these affected tissues do not differentiate under the influence of $D l x$ gene expression but, rather, act as transient signaling centers for growth and patterning. While cell division can be compromised in such cells by the absence of Dlx5 and Dlx6, elevated expression of either Dlx protein appears to antagonize cell division. In cells that normally express these factors then, it is the levels of Dlx 5 and Dlx6 that appear to be important for maintenance of cellular proliferation at wild type rates during development: too little Dlx5 and Dlx6 and cell division can be compromised in some cell types, leading to cell death [34]; too much Dlx5 (and presumably Dlx6) and cell division is antagonized, thereby promoting precocious differentiation $[57,73,74]$. While we do not know that elevated levels of Dlx5 or Dlx6 delay entry into $\mathrm{S}$-phase in all progenitor cell types in which they are expressed, our data in a variety of mesenchymal and epithelial cells suggests this is a likely to be a general phenomenon. A number of studies, furthermore, lead us to conclude that it is the collective functional pool of co-expressed Dlx5 and Dlx6 proteins that is the key factor [69, 75]. Many of the functions of these two proteins are interchangeable; morphological and differentiation defects in $D l \times 5 / 6^{-/-}$mice are rescued by the tissue-specific expression of a single paralog [37, 38] and, in a number of promoter contexts, these two proteins behave in a quantitatively indistinguishable manner [76].

Since the observation that an increase in cell cycle length accompanies the switch from proliferative to neurogenic cell divisions [6] and that a lengthened $G_{1}$ phase is causative for neurogenesis, rather than a consequence $[7,8]$, several studies have revealed a mechanistic link between cyclins, cyclin-dependent kinases, CDK inhibitors, and neurogenic differentiation in the central nervous system [77-79]. In neural progenitors, at least, the time spent in $G_{1}$ appears to be the critical variable while $S, G_{2}$, and $M$ phases proceed on a more invariant schedule [6, 80-82]. Elongation in the length of the cell cycle by antagonism of entry into $S$ phase and the coincident accumulation of differentiation-promoting determinants in a lengthened $G_{1}$ is an attractive model [8] that may well apply to other tissues. Indeed, molecular mechanisms that link cell cycle progression to differentiation in other tissues have been identified [3, 83-87]. Dlx action in this study was consistent with such a model since the effect of expression was to prolong the time spent in $G_{1}$, rather than promoting exit to $G_{0}$. 
Of specific interest, links between Dlx-mediated jaw morphogenesis and cell cycle regulation warrant investigation. Quail-chick chimera studies have revealed the extent to which the neural crest mesenchyme acts as a time-keeper to influence beak size by controlling timing of the transition from neural crest progenitor proliferation to osteoblast differentiation [88]. Mechanistically, the link appears to involve regulation of cyclin D levels, since manipulation of ccnd1 expression prematurely up-regulates osteogenic differentiation markers like Runx2 and results in a smaller beak [88]. Additionally, ventral-specific edn1-mediated proliferation of neural crest-derived cells is known to be required for expansion and outgrowth of the jaw, and is counterbalanced by hand2 [89], a target of Dlx5 and Dlx6 [49, 90]. Thus, Dlx5 and Dlx6 likely regulate differentiation of jaw-forming tissues, at least in part, through antagonism of cell cycle progression. Notably, the cell cycle regulators encoded by dach1, tcf19, and ccnd 2 are all deregulated in the first pharyngeal arch of Dlx5/6 null E10.5 mouse embryos (microarray data published in [91]). In the chick embryo, $c c n d 2$ has been explicitly linked to the coordination of proliferation, differentiation and patterning in discrete progenitor domains in the early chick spinal cord [92]. Ebf1, a gene that has also been implicated in the coordinated regulation of proliferation, survival, and differentiation [93], is a target gene of Dlx5 and/or Dlx6, in multiple tissue contexts [51, 94]. While such circumstantial evidence places Dlx proteins as DNA-binding transcriptional regulators of cell cycle control genes, the extent to which Dlx-mediated regulation of cell cycle progression involves protein-protein interactions with other cell cycle regulators also remains to be investigated.

\section{Conclusions}

The $D l x$ family of homeobox genes are heavily studied for their important functions in patterning and differentiation in vertebrate embryos. While a large body of literature has documented their roles in promoting differentiation of various cell types through the up-regulation of differentiation markers, the potential of $D l x$ genes to promote differentiation by antagonizing the cell cycle has not been addressed. Here, we document a generalized antagonism of cellular proliferation when $D l x 5$ or Dlx6 are over-expressed. Elevated levels of the proteins did not lead to apoptosis or cell cycle exit. Rather, we have revealed a reduced capacity of $D l \times 5$ - and Dlx6-expressing cells to enter S-phase as a specific consequence of elevated levels of Dlx5 and Dlx6 proteins. Our finding that Dlx proteins influence progression through the $G_{1} / S$ checkpoint prompts further work to link $D l x$ genes, morphogenesis, differentiation, and cell cycle progression.

\begin{abstract}
Methods
Plasmids

$R C A S B P(A)$ plasmids encoding $\mathrm{N}$-terminal myc-tagged chick $D l x 5$, N-terminal myc-tagged chick $D l x 6$, or N-terminal myc-tagged mouse $D l x 5 H D^{m}$, as well as $p c D N A 3$ plasmids encoding $\mathrm{N}$-terminal myc-tagged murine $D l x 5$ and N-terminal myc-tagged murine $D l x 6$ have been described and used previously [95]. LZRS-mycDlx6 was made as described for $L Z R S-m y c D l x 5$ [57].
\end{abstract}

\section{Embryos}

Fertile Barred Rock chicken eggs were obtained from the Arkell Poultry barn at the University of Guelph (Guelph, ON), a Canadian Council on Animal Care-certified institution, and incubated at $38{ }^{\circ} \mathrm{C}$ and high humidity for 4 days. Work with early stage chick embryos is not reviewed by the University of Guelph Animal Care Committee, according to Canadian Council on Animal Care guidelines. Embryos were staged according to Hamburger and Hamilton. Limb buds of stage 22-24 embryos were dissected in Puck's Saline G (PSG) [96]. Tissue was digested with $0.25 \%$ Trypsin in Calcium- \& Magnesium-free PSG plus 10\% fetal calf serum. Digested tissue was triturated with a flame-burnished Pasteur pipette until a single cell suspension was observed microscopically and complete media was added. Cells were counted, centrifuged at $900 \mathrm{xg}$ for $5 \mathrm{~min}$. and resuspended at $2 \times 10^{7}$ cells $/ \mathrm{ml}$.

\section{Cell lines, transfection, and selection}

DF-1 (ATCC CRL-12203), HEK-293 (ATCC CRL-1573), HEK-293 T (ATCC CRL-3216), C2C12 (ATCC CRL-1772), and primary chick embryo limb bud cells were cultured at $37{ }^{\circ} \mathrm{C}$ and $5 \% \mathrm{CO}_{2}$ in Dulbecco's Modified Eagle's Medium (DMEM) supplemented with 10\% (or $20 \%$ for $\mathrm{C} 2 \mathrm{C} 12$ ) fetal bovine serum, $100 \mathrm{U} / \mathrm{ml}$ penicillin, $100 \mu \mathrm{g} / \mathrm{ml}$ streptomycin, and $2 \mathrm{mM} \mathrm{L}$-glutamine. In some experiments, cells were cultured on glass coverslips that had been coated with $0.1 \mathrm{M}$ poly-D-lysine for $30 \mathrm{~min}$. then washed twice with sterile deionized water and once with DMEM. DF-1 cells were transfected at sub-confluency in a $6 \mathrm{~cm}$ dish with $4 \mu \mathrm{g} \operatorname{RCASBP}(A)$ plasmids using $4.5 \mu \mathrm{g}$ polyethylenimine (PEI) per $\mu \mathrm{g}$ of plasmid DNA. Cells were expanded to $10 \mathrm{~cm}$ dishes $24 \mathrm{~h}$ post transfection. In order to enrich for Dlx-expressing cells we relied on the ability of the replication-competent virus made by transfected cells to transduce untransfected cells in the dish. Thus, transfected populations were expanded, after a further $48 \mathrm{~h}$, to $15 \mathrm{~cm}$ dishes along with one quarter of a sub-confluent (untransfected) $10 \mathrm{~cm}$ dish, the virus-containing media from the transfected cells, and $10 \mathrm{ml}$ of fresh complete DMEM. Cells were collected $48 \mathrm{~h}$ later for growth assays. HEK293, and HEK293T cells were transfected at 
sub-confluency in $6 \mathrm{~cm}$ dishes with $4 \mu \mathrm{g}$ of $L Z R S$ plasmids using PEI as above. Cells were maintained at sub-confluency and selected with $4 \mu \mathrm{g} / \mathrm{ml}$ Puromycin (Fisher Scientific) for 3-7 days to enrich for Dlx-expressing cells. C2C12 cells were transfected in suspension with $4 \mu \mathrm{g} p c D N A 3$ plasmids, using $6 \mu \mathrm{l}$ Effectene Transfection Reagent (Qiagen) per $\mu$ g plasmid DNA and EC buffer supplemented with $0.4 \mathrm{M}$ trehalose. Cells were maintained at sub-confluency and selected over 4 days with $1 \mathrm{mg} / \mathrm{ml}$ G418 (BioShop). $1.6 \times 10^{6}$ chick embryo limb bud cells, at a density of $2 \times 10^{7}$ cells $/ \mathrm{ml}$, were transfected in suspension with $3 \mu \mathrm{g}$ of $\operatorname{RCASBP}(A)$ plasmids and Effectene, as above. The DNA/cell mixture was seeded directly into the cell viability assay.

\section{Resazurin cell viability assay}

Cell populations were seeded into 96-well plates at equal density in $100 \mu \mathrm{l}$ of supplemented DMEM. Each day, $100 \mu \mathrm{l}$ of $0.05 \mathrm{mM}$ resazurin (Sigma) in supplemented DMEM was added per well. Fluorescence was measured at Ex516 $\lambda$ and Em590 $\lambda$ in a microplate fluorescence reader immediately after resazurin addition and after $4 \mathrm{~h}$ of incubation at $37^{\circ} \mathrm{C}$ and $5 \% \mathrm{CO}_{2}$ to aquire a measure of live cells. Measurements on new cells were repeated every $24 \mathrm{~h}$ for 5 days. Background-subtracted changes in fluorescence were normalized against the reading taken at day zero.

\section{Caspase- 3 activation assay}

To avoid any bias in measurements of caspase- 3 activity, floating cells were collected prior to trypsinizing the adherent monolayer at each time point. Cells were incubated for $30 \mathrm{~min}$. on ice in cell lysis buffer $(50 \mathrm{mM}$ HEPES, pH 7.4; 0.1\% CHAPS; $0.1 \mathrm{mM}$ EDTA; $1 \mathrm{mM}$ DTT) at a density of $1.5 \times 10^{6}$ cells $/ 50 \mu$ l. Extracts were centrifuged at $20,000 \mathrm{xg}$ for $10 \mathrm{~min}$. at $4{ }^{\circ} \mathrm{C}$. Caspase activity was measured by mixing $25 \mu \mathrm{l}$ of cell extract with $75 \mu \mathrm{l}$ of reaction buffer $(50 \mathrm{mM}$ HEPES, pH 7.4; $100 \mathrm{mM} \mathrm{NaCl}$; 0.1\% CHAPS; $10 \mathrm{mM}$ DTT; 1 mM EDTA; $10 \%$ glycerol) and $100 \mu \mathrm{l}$ of $60 \mu \mathrm{M}$ fluorogenic caspase-3 substrate (Ac-DEVD-AMC). The amount of AMC released was measured at $37^{\circ} \mathrm{C}$ every $5 \mathrm{~min}$. for $90 \mathrm{~min}$. using a BIO-TEK Flx800 microplate fluorescence reader with $360 / 40 \mathrm{~nm}$ Fluorescence Filter (BIO-TEK) for excitation and 460/40 nm Fluorescence Filter (BIO-TEK) for emission. Protein concentration was determined using BCA protein assay kit (Pierce) at $454 \mathrm{~nm}$, allowing the relative fluorescence units released per minute, per $\mu \mathrm{g}$ of protein to be determined.

\section{Immunoblotting}

Cells were collected in chilled Dulbecco's Phosphate Buffered Saline (Hyclone) and lysed with sonication in high salt lysis buffer (50 mM Tris, pH 8; $500 \mathrm{mM} \mathrm{NaCl}$; $1 \%$ Triton X-100) with protease inhibitors (Complete
Mini Protease Inhibitor; Roche). Protein was quantified and separated by SDS-PAGE in a $13 \%$ poly-acrylamide gel then transferred to PVDF. Membranes were blocked for at least $1 \mathrm{~h}$ in $5 \%$ skim milk powder in PBS containing $0.1 \%$ Tween-20. Membranes were incubated for at least $2 \mathrm{~h}$ in primary antibodies: $\alpha$-MYC (1:500 monoclonal 9E10 in blocking solution) or anti- $\beta$-actin (Genetex at 1:2000) and $1 \mathrm{~h}$ in secondary (1:10,000 HRP-conjugated goat- $\alpha$-mouse, Bio-Rad). Immunoreactive bands were visualized with Western Lightning Chemiluminescence Reagent Plus (PerkinElmer Life Sciences) and imaged with a Bio-Rad molecular Imager Chemi-Doc XRS+ and ImageLab software (Bio-Rad).

\section{TUNEL assay}

Cells were transfected in suspension directly onto poly-D-lysine-coated coverslips and collected $24 \mathrm{~h}$ post transfection. Cells were fixed in $3.7 \%$ formaldehyde in PBS and permeabilized using $0.25 \%$ Triton-X-100 in PBS. An untransfected slide was treated with DNase I to determine the level of fluorescence above background at which to count cells as positive for extensive DNA damage. DNA breaks were detected with a Click-iT ${ }^{\circ}$ TUNEL Alexa Fluor 594 Imaging Assay (Life Technologies).

\section{Indirect immunofluorescence}

Following Click-iT ${ }^{\circ}$ chemistry, coverslips were washed twice in PBS supplemented with $10 \mathrm{mM}$ glycine (PBS-G). Myc-tagged Dlx proteins were detected with 9E10 mouse monoclonal antibody diluted 1:50 with $3 \%$ bovine serum albumin (BSA) in PBS-G for $2 \mathrm{~h}$ at room temperature in the dark. Coverslips were washed twice with PBS-G then incubated for $45 \mathrm{~min}$. with secondary FITC-conjugated goat anti-mouse antibody (Genetex) diluted 1:100 with $3 \%$ BSA in PBS-G. Coverslips were then washed 3 times with PBS-G and incubated for 30 min. in $5 \mu \mathrm{g} / \mathrm{ml} \mathrm{Hoechst} 33342$ (Molecular Probes) at room temperature in the dark. Coverslips were washed twice with PBS and once with sterile deionized water and allowed to dry before mounting in 1,4-19 diazabicyclo [2.2.2] octane (DABCO at $10 \mathrm{mg} / \mathrm{ml}$ in 1:9 PBS: Glycerol; $0.02 \%$ sodium azide). Ki67 was detected with the same protocol using purified mouse anti-Ki67 monoclonal (BD Pharmingen \#550609) at 1:500 dilution in PBS-G + 3\% BSA for $2 \mathrm{~h}$ and donkey anti-mouse secondary conjugated to Alexa594 (Life Technologies) at 1:500 dilution in PBS-G + 3\% BSA for $45 \mathrm{~min}$. Due to antibody incompatibility, Dlx proteins were detected by proxy from co-transfected plasmid encoding nuclear GFP.

\section{EdU incorporation}

Cells were transfected in suspension directly onto poly-D-lysine-coated coverslips and cultured for $24 \mathrm{~h}$ 
before addition of EdU. Transfected cells were incubated for various times with $10 \mu \mathrm{M}$ EdU in DMEM at $37^{\circ} \mathrm{C}$, $5 \% \mathrm{CO} 2$, then fixed in $3.7 \%$ formaldehyde in PBS and permeabilized using $0.5 \%$ Triton-X-100 in PBS. EdU was detected with a Click-iT ${ }^{\circ}$ EdU Alexa Fluor ${ }^{\circ} 594$ Imaging Kit (Life Technologies) according to the manufacturer's instructions. Indirect immunodetection of epitopetagged proteins was performed, as above, after EdU detection.

\section{Flow cytometry}

Transfected cells were trypsinized and counted $24 \mathrm{~h}$ post seeding. Cells were centrifuged at $900 \mathrm{xg}$ and resuspended at $1 \times 10^{6}$ cells $/ \mathrm{ml}$ in Dulbecco's PBS. Cells were centrifuged again at $900 \mathrm{xg}$ and fixed with chilled $\left(-20^{\circ}\right.$ C) $70 \%$ ethanol with vortexing. Cells were then incubated at $-20^{\circ} \mathrm{C}$ for at least $24 \mathrm{~h}$ then pelleted at 3000 xg. Cell pellets were washed twice with PBS then resuspended in $50 \mu \mathrm{l}$ of $100 \mu \mathrm{g} / \mathrm{ml}$ RNase A (per $1 \times 10^{6}$ cells) and incubated at room temperature for $10 \mathrm{~min} .400 \mu \mathrm{l}$ of $50 \mu \mathrm{g} / \mathrm{ml}$ propidium iodide in PBS was added (per $1 \times$ $10^{6}$ cells) and incubated for $30 \mathrm{~min}$. at $37^{\circ} \mathrm{C}$. DNA content, represented as propidium iodide fluorescence, was quantitated using a Cytomics FC 500MPL flow cytometer (Beckman Coulter) at excitation of $488 \mathrm{~nm}$. FL1 (Em 525) was used to detect FITC fluorescence and FL3 (Em 610) was used to detect propidium iodide. FL3 histograms were analyzed using the MultiCycle AV DNA analysis software (Phoenix Flow Systems) available in the FCS Express 4 Plus-Research Edition program (De Novo Software). The histogram was fit with the SL G21 S0 one cycle fitting model. G2/G1 ratio was set at 1.93 and background was removed before G1, S and G2 DNA content was analyzed.

\section{Statistical analysis}

All statistical analysis was performed using Prism (GraphPad). All linear increases in growth curves and cumulative labeling EdU incorporation assays were fit with a linear regression model, considering each replicate $\mathrm{Y}$ value as an individual point. The slopes of any 2 lines were compared with a two-tailed test of the null hypothesis that the slopes were identical. A $p$ value less than or equal to 0.05 was interpreted as a rejection of the null hypothesis. If the $\mathrm{p}$ value was greater than 0.05 , the intercepts of the slopes were compared. A second $p$ value was calculated testing the null hypothesis that the lines were identical. A p value of less than or equal to 0.05 was interpreted as a rejection of the null hypothesis. Two-way analysis of variance (ANOVA) was performed on any data that had multiple variables affecting the outcome, including the time-point caspase-3 activation assay, $4 \mathrm{~h}$ EdU incorporation assay and TUNEL. Other caspase-3 activation assays were analyzed using a one-way ANOVA. Flow cytometry data was compared with unpaired $t$-tests, using the Holm-Sidak method with an alpha of $5 \%$ to correct for multiple comparisons. In all of these instances, a $\mathrm{p}$ value less than or equal to 0.05 was considered statistically significant.

\section{Abbreviations}

ANOVA: Analysis of variance; BSA: Bovine serum albumin; DABCO: 1,4-19 diazabicyclo [2.2.2] octane; DMEM: Delbecco's Modifed Eagle's Medium; EdU: 5-ethynyl-2'-deoxyuridine; FITC: Fluorescein isothiocyanate; GF: Growth fraction; LI: Labeling index; PBS: Phosphate-buffered saline; PBS-G: Phosphatebuffered saline containing glycine; PEI: Polyethylenimine; PSG: Puck's saline with glucose; RFU: Relative fluorescence unit; SEM: Standard error of the mean; TUNEL: Terminal deoxynucleotidyl transferase dUTP nick end labeling

\section{Acknowledgements}

We thank undergraduate project students Cassi Nicodemo for help with EdU and Ki67 assays and Elinor Farrell for help with the HEK293 growth assay.

\section{Funding}

This work was supported by the Natural Sciences and Engineering Research Council of Canada (Discovery Grant 249773-2013 to AJB and scholarship CGS-M to RKM).

\section{Availability of data and materials}

The datasets used and/or analysed during the current study are available from the corresponding author on reasonable request.

\section{Authors' contributions}

RKM \& AJB conceived and designed the study, RKM \& PRS collected data, all authors analyzed data, and RKM \& AJB wrote and edited the manuscript. All authors read and approved the final manuscript.

\section{Ethics approval and consent to participate}

Work with early stage chick embryos is not reviewed by the University of Guelph Animal Care Committee, according to Canadian Council on Animal Care guidelines.

\section{Consent for publication}

Not applicable.

\section{Competing interests}

The authors declare that they have no competing interests.

\section{Publisher's Note}

Springer Nature remains neutral with regard to jurisdictional claims in published maps and institutional affiliations.

Received: 13 September 2018 Accepted: 2 April 2019

Published online: 11 April 2019

\section{References}

1. Langley AR, Smith JC, Stemple DL, Harvey SA. New insights into the maternal to zygotic transition. Development. 2014;141(20):3834-41.

2. Buttitta LA, Edgar BA. Mechanisms controlling cell cycle exit upon terminal differentiation. Curr Opin Cell Biol. 2007;19(6):697-704.

3. Soufi A, Dalton S. Cycling through developmental decisions: how cell cycle dynamics control pluripotency, differentiation and reprogramming. Development. 2016;143(23):4301-11.

4. Calder A, Roth-Albin I, Bhatia S, Pilquil C, Lee JH, Bhatia M, Levadoux-Martin M, McNicol J, Russell J, Collins T, et al. Lengthened G1 phase indicates differentiation status in human embryonic stem cells. Stem Cells Dev. 2013; 22(2):279-95.

5. Coronado D, Godet M, Bourillot PY, Tapponnier Y, Bernat A, Petit M, Afanassieff M, Markossian S, Malashicheva A, lacone R, et al. A short G1 phase is an intrinsic determinant of naive embryonic stem cell pluripotency. Stem Cell Res. 2013;10(1):118-31. 
6. Takahashi T, Nowakowski RS, Caviness VS Jr. The cell cycle of the pseudostratified ventricular epithelium of the embryonic murine cerebral wall. J Neurosci. 1995;15(9):6046-57.

7. Calegari F, Haubensak W, Haffner C, Huttner WB. Selective lengthening of the cell cycle in the neurogenic subpopulation of neural progenitor cells during mouse brain development. J Neurosci. 2005;25(28):6533-8.

8. Calegari F, Huttner WB. An inhibition of cyclin-dependent kinases that lengthens, but does not arrest, neuroepithelial cell cycle induces premature neurogenesis. J Cell Sci. 2003;116(Pt 24):4947-55.

9. Halevy O, Novitch BG, Spicer DB, Skapek SX, Rhee J, Hannon GJ, Beach D, Lassar AB. Correlation of terminal cell cycle arrest of skeletal muscle with induction of p21 by MyoD. Science. 1995;267(5200):1018-21.

10. Parker SB, Eichele G, Zhang P, Rawls A, Sands AT, Bradley A, Olson EN, Harper JW, Elledge SJ. p53-independent expression of p21Cip1 in muscle and other terminally differentiating cells. Science. 1995;267(5200):1024-7.

11. Busanello A, Battistelli C, Carbone M, Mostocotto C, Maione R. MyoD regulates p57kip2 expression by interacting with a distant cis-element and modifying a higher order chromatin structure. Nuc Acids Res. 2012; 40(17):8266-75.

12. Papetti M, Wontakal SN, Stopka T, Skoultchi Al. GATA-1 directly regulates p21 gene expression during erythroid differentiation. Cell Cycle. 2010;9(10):1972-80.

13. Siatecka M, Lohmann F, Bao S, Bieker JJ. EKLF directly activates the p21WAF1/CIP1 gene by proximal promoter and novel intronic regulatory regions during erythroid differentiation. Mol Cell Biol. 2010;30(11):2811-22.

14. Lacomme M, Liaubet $L$, Pituello F, Bel-Vialar S. NEUROG2 drives cell cycle exit of neuronal precursors by specifically repressing a subset of cyclins acting at the G1 and S phases of the cell cycle. Mol Cell Biol. 2012;32(13): 2596-607.

15. Choksi SP, Southall TD, Bossing T, Edoff K, de Wit E, Fischer BE, van Steensel $B$, Micklem G, Brand AH. Prospero acts as a binary switch between selfrenewal and differentiation in Drosophila neural stem cells. Dev Cell. 2006; 11(6):775-89.

16. Li L, Vaessin H. Pan-neural Prospero terminates cell proliferation during Drosophila neurogenesis. Genes Dev. 2000;14(2):147-51.

17. Skapek SX, Rhee J, Spicer DB, Lassar AB. Inhibition of myogenic differentiation in proliferating myoblasts by cyclin D1-dependent kinase. Science. 1995:267(5200):1022-4.

18. Rao SS, Chu C, Kohtz DS. Ectopic expression of cyclin D1 prevents activation of gene transcription by myogenic basic helix-loop-helix regulators. Mol Cell Biol. 1994;14(8):5259-67.

19. Ali F, Hindley C, McDowell G, Deibler R, Jones A, Kirschner M, Guillemot F, Philpott A. Cell cycle-regulated multi-site phosphorylation of Neurogenin 2 coordinates cell cycling with differentiation during neurogenesis. Development. 2011;138(19):4267-77.

20. Hindley C, Ali F, McDowell G, Cheng K, Jones A, Guillemot F, Philpott A. Post-translational modification of Ngn2 differentially affects transcription of distinct targets to regulate the balance between progenitor maintenance and differentiation. Development. 2012;139(10):1718-23.

21. Beanan MJ, Sargent TD. Regulation and function of dlx3 in vertebrate development. Dev Dyn. 2000;218(4):545-53.

22. Bendall AJ, Abate-Shen C. Roles for Msx and dlx homeoproteins in vertebrate development. Gene. 2000;247(1-2):17-31.

23. Duverger $\mathrm{O}$, Morasso Ml. Role of homeobox genes in the patterning, specification, and differentiation of ectodermal appendages in mammals. J Cell Physiol. 2008;216(2):337-46.

24. Merlo GR, Zerega B, Paleari L, Trombino S, Mantero S, Levi G. Multiple functions of D/x genes. Int J Dev Biol. 2000;44(6):619-26.

25. Panganiban $\mathrm{G}$, Rubenstein $\mathrm{J}$. Developmental functions of the distal-less/dlx homeobox genes. Development. 2002;129(19):4371-86.

26. Samee N, de Vernejoul MC, Levi G. Role of DLX regulatory proteins in osteogenesis and chondrogenesis. Crit Rev Eukaryot Gene Expr. 2007;17(3):173-86.

27. Zerucha T, Ekker M. Distal-less-related homeobox genes of vertebrates: evolution, function, and regulation. Biochem Cell Biol. 2000;78(5):593-601.

28. Wang Y, Dye CA, Sohal V, Long JE, Estrada RC, Roztocil T, Lufkin T, Deisseroth K, Baraban SC, Rubenstein JL. D/x5 and D/x6 regulate the development of parvalbumin-expressing cortical interneurons. J Neurosci. 2010;30(15):5334-45.

29. Long JE, Garel S, Depew MJ, Tobet S, Rubenstein JL. DLX5 regulates development of peripheral and central components of the olfactory system. J Neurosci. 2003;23(2):568-78.
30. Levi G, Puche AC, Mantero S, Barbieri O, Trombino S, Paleari L, Egeo A, Merlo $\mathrm{GR}$. The Dlx5 homeodomain gene is essential for olfactory development and connectivity in the mouse. Mol Cell Neurosci. 2003;22(4):530-43.

31. Garaffo G, Conte D, Provero P, Tomaiuolo D, Luo Z, Pinciroli P, Peano C, D'Atri l, Gitton Y, Etzion T, et al. The Dlx5 and Foxg1 transcription factors, linked via miRNA-9 and -200, are required for the development of the olfactory and GnRH system. Mol Cell Neurosci. 2015;68:103-19.

32. Perera M, Merlo GR, Verardo S, Paleari L, Corte G, Levi G. Defective neuronogenesis in the absence of D/×5. Mol Cell Neurosci. 2004;25(1):153-61.

33. Merlo GR, Paleari L, Mantero S, Zerega B, Adamska M, Rinkwitz S, Bober E, Levi G. The D/x5 homeobox gene is essential for vestibular morphogenesis in the mouse embryo through a BMP4-mediated pathway. Dev Biol. 2002; 248(1):157-69.

34. Robledo RF, Lufkin T. Dlx5 and Dlx6 homeobox genes are required for specification of the mammalian vestibular apparatus. Genesis. 2006;44(9): 425-37.

35. Acampora D, Merlo GR, Paleari L, Zerega B, Postiglione MP, Mantero S, Bober E, Barbieri O, Simeone A, Levi G. Craniofacial, vestibular and bone defects in mice lacking the distal-less-related gene Dlx5. Development. 1999;126:3795-809.

36. Depew MJ, Liu JK, Long JE, Presley R, Meneses JJ, Pedersen RA, Rubenstein JLR. D/x5 regulates regional development of the branchial arches and sensory capsules. Development. 1999;126:3831-46.

37. Zhu H, Bendall AJ. Dlx5 is a cell autonomous regulator of chondrocyte hypertrophy in mice and functionally substitutes for Dlx6 during endochondral ossification. PLoS One. 2009;4(11):e8097.

38. Robledo RF, Rajan L, Li X, Lufkin T. The D/x5 and D/x6 homeobox genes are essential for craniofacial, axial, and appendicular skeletal development. Genes Dev. 2002;16(9):1089-101.

39. Hassan MQ, Javed A, Morasso Ml, Karlin J, Montecino M, van Wijnen AJ, Stein GS, Stein JL, Lian JB. Dlx3 transcriptional regulation of osteoblast differentiation: temporal recruitment of Msx2, Dlx3, and Dlx5 homeodomain proteins to chromatin of the osteocalcin gene. Mol Cell Biol. 2004;24(20): 9248-61.

40. Hojo H, Ohba S, He X, Lai LP, McMahon AP. Sp7/Osterix is restricted to bone-forming vertebrates where it acts as a dlx co-factor in osteoblast specification. Dev Cell. 2016;37(3):238-53.

41. Newberry EP, Latifi T, Towler DA. Reciprocal regulation of osteocalcin transcription by the homeodomain proteins Msx2 and Dlx5. Biochem. 1998; 37:16360-8

42. Roca H, Phimphilai M, Gopalakrishnan R, Xiao G, Franceschi RT. Cooperative interactions between RUNX2 and homeodomain protein-binding sites are critical for the osteoblast-specific expression of the bone sialoprotein gene. J Biol Chem. 2005;280(35):30845-55.

43. Wang S, Sasaki Y, Zhou L, Matsumura H, Araki S, Mezawa M, Takai H, Chen Z, Ogata Y. Transcriptional regulation of bone sialoprotein gene by interleukin-11. Gene. 2011:476(1-2):46-55.

44. Hassan MQ, Tare RS, Lee SH, Mandeville M, Morasso MI, Javed A, van Wijnen AJ, Stein JL, Stein GS, Lian JB. BMP2 commitment to the osteogenic lineage involves activation of Runx2 by DLX3 and a homeodomain transcriptional network. J Biol Chem. 2006;281(52):40515-26.

45. Jang WG, Kim EJ, Lee KN, Son HJ, Koh JT. AMP-activated protein kinase (AMPK) positively regulates osteoblast differentiation via induction of Dl×5dependent Runx2 expression in MC3T3E1 cells. Biochem Biophys Res Comm. 2011:404(4):1004-9.

46. Kawane T, Komori H, Liu W, Moriishi T, Miyazaki T, Mori M, Matsuo Y, Takada $Y$, Izumi S, Jiang Q, et al. Dlx5 and Mef2 regulate a novel runx2 enhancer for osteoblast-specific expression. J Bone Miner Res. 2014;29(9):1960-9.

47. Lee MH, Kim YJ, Yoon WJ, Kim Jl, Kim BG, Hwang YS, Wozney JM, Chi XZ, Bae SC, Choi KY, et al. Dlx5 specifically regulates Runx2 type II expression by binding to homeodomain-response elements in the Runx2 distal promoter. J Biol Chem. 2005:280(42):35579-87.

48. Ulsamer A, Ortuno MJ, Ruiz S, Susperregui AR, Osses N, Rosa JL, Ventura F. BMP-2 induces Osterix expression through up-regulation of Dlx5 and its phosphorylation by p38. J Biol Chem. 2008;283(7):3816-26.

49. Charité J, McFadden DG, Merlo G, Levi G, Clouthier DE, Yanagisawa M, Richardson JA, Olson EN. Role of Dlx6 in regulation of an endothelin-1dependent, dHAND branchial arch enhancer. Genes Dev. 2001;15:3039-49.

50. Pan ZZ, Kronenberg MS, Huang DY, Sumoy L, Rogina B, Lichtler AC, Upholt WB. MSX2 expression in the apical ectoderm ridge is regulated by an MSX2 and Dlx5 binding site. Biochem Biophys Res Commun. 2002;290(3):955-61. 
51. Sajan SA, Rubenstein JL, Warchol ME, Lovett M. Identification of direct downstream targets of Dlx5 during early inner ear development. Hum Mol Genet. 2011;20(7):1262-73.

52. Cavalli LR, Man YG, Schwartz AM, Rone JD, Zhang Y, Urban CA, Lima RS, Haddad BR, Berg PE. Amplification of the BP1 homeobox gene in breast cancer. Cancer Genet Cytogenet. 2008;187(1):19-24.

53. Kato T, Sato N, Takano A, Miyamoto M, Nishimura H, Tsuchiya E, Kondo S, Nakamura Y, Daigo Y. Activation of placenta-specific transcription factor distal-less homeobox 5 predicts clinical outcome in primary lung cancer patients. Clin Cancer Res. 2008;14(8):2363-70.

54. Tan Y, Timakhov RA, Rao M, Altomare DA, Xu J, Liu Z, Gao Q, Jhanwar SC, Di Cristofano A, Wiest DL, et al. A novel recurrent chromosomal inversion implicates the homeobox gene Dlx5 in T-cell lymphomas from Lck-Akt2 transgenic mice. Cancer Res. 2008;68(5):1296-302.

55. Tan Y, Cheung M, Pei J, Menges CW, Godwin AK, Testa JR. Upregulation of DLX5 promotes ovarian cancer cell proliferation by enhancing IRS-2-AKT signaling. Cancer Res. 2010;70(22):9197-206.

56. Zhou JD, Yang J, Guo H, Deng ZQ, Wen XM, Yang L, Yin JY, Xiao GF, Lin J, Qian J. BP1 overexpression is associated with adverse prognosis in de novo acute myeloid leukemia. Leukemia Lymphoma. 2016;57(4):828-34.

57. Bendall AJ, Hu G, Levi G, Abate-Shen C. Dlx5 regulates chondrocyte differentiation at multiple stages. Int J Dev Biol. 2003;47(5):335-44.

58. Kim YJ, Lee MH, Wozney JM, Cho JY, Ryoo HM. Bone morphogenetic protein-2-induced alkaline phosphatase expression is stimulated by Dlx5 and repressed by Msx2. J Biol Chem. 2004;279(49):50773-80.

59. Lee MH, Kim YJ, Kim HJ, Park HD, Kang AR, Kyung HM, Sung JH, Wozney JM, Ryoo HM. BMP-2-induced Runx2 expression is mediated by Dlx5, and TGF-b1 opposes the BMP-2-induced osteoblast differentiation by suppression of Dlx5 expression. J Biol Chem. 2003;278(36):34387-94

60. Lee MH, Kwon TG, Park HS, Wozney JM, Ryoo HM. BMP-2-induced Osterix expression is mediated by Dlx5 but is independent of Runx2. Biochem Biophys Res Commun. 2003;309(3):689-94.

61. Ryoo HM, Lee MH, Kim YJ. Critical molecular switches involved in BMP2-induced osteogenic differentiation of mesenchymal cells. Gene. 2006; 366(1):51-7.

62. DuBridge RB, Tang P, Hsia HC, Leong PM, Miller JH, Calos MP. Analysis of mutation in human cells by using an Epstein-Barr virus shuttle system. Mol Cell Biol. 1987;7(1):379-87.

63. Bargonetti J, Reynisdottir I, Friedman PN, Prives C. Site-specific binding of wild-type p53 to cellular DNA is inhibited by SV40 T antigen and mutant p53. Genes Dev. 1992;6(10):1886-98.

64. Bocchetta M, Eliasz S, De Marco MA, Rudzinski J, Zhang L, Carbone M. The SV40 large T antigen-p53 complexes bind and activate the insulin-like growth factor-l promoter stimulating cell growth. Cancer Res. 2008;68(4):1022-9.

65. Caracciolo V, Reiss K, Khalili K, De Falco G, Giordano A. Role of the interaction between large $\mathrm{T}$ antigen and $\mathrm{Rb}$ family members in the oncogenicity of JC virus. Oncogene. 2006;25(38):5294-301.

66. Segawa K, Minowa A, Sugasawa K, Takano T, Hanaoka F. Abrogation of p53-mediated transactivation by SV40 large T antigen. Oncogene. 1993; 8(3):543-8.

67. Jiang D, Srinivasan A, Lozano G, Robbins PD. SV40 T antigen abrogates p53mediated transcriptional activity. Oncogene. 1993;8(10):2805-12.

68. Nowakowski RS, Lewin SB, Miller MW. Bromodeoxyuridine immunohistochemical determination of the lengths of the cell cycle and the DNA-synthetic phase for an anatomically defined population. J Neurocytol. 1989;18(3):311-8.

69. Beverdam A, Merlo GR, Paleari L, Mantero S, Genova F, Barbieri O, Janvier P, Levi G. Jaw transformation with gain of symmetry after D/x5/D/x6 inactivation: Mirror of the past? Genesis. 2002;34(4):221-7.

70. Depew MJ, Lufkin T, Rubenstein JL. Specification of jaw subdivisions by D/x genes. Science. 2002;298(5592):381-5.

71. Depew MJ, Simpson CA, Morasso M, Rubenstein JL. Reassessing the $\mathrm{dlx}$ code: the genetic regulation of branchial arch skeletal pattern and development. J Anat. 2005;207(5):501-61.

72. Merlo G, Paleari L, Mantero S, Genova F, Beverdam A, Palmisano GL, Barbieri O, Levi G. Mouse model of split hand/foot malformation type I. Genesis. 2002;33(2):97-101.

73. Chin HJ, Fisher MC, Li Y, Ferrari D, Wang CK, Lichtler AC, Dealy CN, Kosher RA. Studies on the role of DIx5 in regulation of chondrocyte differentiation during endochondral ossification in the developing mouse limb. Develop Growth Differ. 2007:49(6):515-21.
74. Ferrari D, Kosher RA. DIx5 is a positive regulator of chondrocyte differentiation during endochondral ossification. Dev Biol. 2002;252(2):257-70.

75. Bendall AJ. Direct evidence of allele equivalency at the D/x5/6 locus. Genesis. 2016:54(5):272-6.

76. Quach A, MacKenzie RK, Bendall AJ. Measuring inputs to a common function: the case of Dlx5 and Dlx6. Biochem Biophys Res Comm. 2016;478:371-7.

77. Watanabe N, Kageyama R, Ohtsuka T. Hbp1 regulates the timing of neuronal differentiation during cortical development by controlling cell cycle progression. Development. 2015;142(13):2278-90.

78. Miles A, Tropepe V. Coordinating progenitor cell cycle exit and differentiation in the developing vertebrate retina. Neurogenesis (Austin). 2016;3(1):e1161697.

79. Hindley C, Philpott A. Co-ordination of cell cycle and differentiation in the developing nervous system. Biochem J. 2012;444(3):375-82.

80. Caviness VS Jr, Goto T, Tarui T, Takahashi T, Bhide PG, Nowakowski RS. Cell output, cell cycle duration and neuronal specification: a model of integrated mechanisms of the neocortical proliferative process. Cereb Cortex. 2003; 13(6):592-8.

81. Delalle I, Takahashi T, Nowakowski RS, Tsai LH, Caviness VS Jr. Cyclin E-p27 opposition and regulation of the G1 phase of the cell cycle in the murine neocortical PVE: a quantitative analysis of MRNA in situ hybridization. Cereb Cortex. 1999:9(8):824-32

82. Miyama S, Takahashi T, Nowakowski RS, Caviness VS Jr. A gradient in the duration of the G1 phase in the murine neocortical proliferative epithelium. Cereb Cortex. 1997;7(7):678-89.

83. Azzarelli R, Hurley C, Sznurkowska MK, Rulands S, Hardwick L, Gamper I, Ali F, McCracken L, Hindley C, McDuff F, et al. Multi-site Neurogenin3 phosphorylation controls pancreatic endocrine differentiation. Dev Cell. 2017;41(3):274-286 e275

84. Krentz NAJ, van Hoof D, Li Z, Watanabe A, Tang M, Nian C, German MS, Lynn FC. Phosphorylation of NEUROG3 links endocrine differentiation to the cell cycle in pancreatic progenitors. Dev Cell. 2017;41(2):129-142 e126.

85. Sela Y, Molotski N, Golan S, Itskovitz-Eldor J, Soen Y. Human embryonic stem cells exhibit increased propensity to differentiate during the G1 phase prior to phosphorylation of retinoblastoma protein. Stem Cells. 2012;30(6): 1097-108.

86. Li VC, Kirschner MW. Molecular ties between the cell cycle and differentiation in embryonic stem cells. Proc Natl Acad Sci U S A. 2014; 111(26):9503-8

87. Ishidate T, Elewa A, Kim S, Mello CC, Shirayama M. Divide and differentiate: CDK/cyclins and the art of development. Cell Cycle. 2014;13(9):1384-91.

88. Hall J, Jheon AH, Ealba EL, Eames BF, Butcher KD, Mak SS, Ladher R, Alliston T, Schneider RA. Evolution of a developmental mechanism: species-specific regulation of the cell cycle and the timing of events during craniofacial osteogenesis. Dev Biol. 2014;385(2):380-95.

89. Sasaki MM, Nichols JT, Kimmel CB. edn1 and hand2 interact in early regulation of pharyngeal arch outgrowth during zebrafish development. PLoS One. 2013;8(6):e67522.

90. Iklé JM, Artinger KB, Clouthier DE. Identification and characterization of the zebrafish pharyngeal arch-specific enhancer for the basic helix-loop-helix transcription factor Hand2. Dev Biol. 2012;368(1):118-26.

91. Jeong J, Li X, McEvilly RJ, Rosenfeld MG, Lufkin T, Rubenstein JL. DlX genes pattern mammalian jaw primordium by regulating both lower jaw-specific and upper jaw-specific genetic programs. Development. 2008;135(17):2905-16.

92. Lobjois V, Benazeraf B, Bertrand N, Medevielle F, Pituello F. Specific regulation of cyclins D1 and D2 by FGF and Shh signaling coordinates cell cycle progression, patterning, and differentiation during early steps of spinal cord development. Dev Biol. 2004:273(2):195-209.

93. Györy I, Boller S, Nechanitzky R, Mandel E, Pott S, Liu E, Grosschedl R. Transcription factor Ebf1 regulates differentiation stage-specific signaling, proliferation, and survival of B cells. Genes Dev. 2012;26(7):668-82.

94. Fazel Darbandi S, Poitras L, Monis S, Lindtner S, Yu M, Hatch G, Rubenstein $J$, Ekker M. Functional consequences of I56ii dlx enhancer deletion in the developing mouse forebrain. Dev Biol. 2016;420(1):32-42.

95. Hsu SH, Noamani B, Abernethy DE, Zhu H, Levi G, Bendall AJ. Dlx5- and Dlx6-mediated chondrogenesis: differential domain requirements for a conserved function. Mech Dev. 2006;123(11):819-30.

96. Puck TT, Cieciura SJ, Robinson A. Genetics of somatic mammalian cells. III. Long-term cultivation of euploid cells from human and animal subjects. J Exp Med. 1958;108(6):945-56. 